\title{
中性子と精密工学
}

\section{中性子小角散乱法とその材料開発への

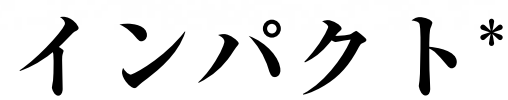

Small-Angle Neutron Scattering Technique and Its Impact on Materials Science

\section{大沼正人 ${ }^{* *}$ 佐藤 馨*** \\ Masato OHNUMA and Kaoru SATO}

Key words small-angle scattering, microstructure, compact neutron source, advanced steels

\section{1.はじめに}

金属材料に扔ける小角散乱法の利用研究は X 線を中心 に活発に行われ, 特に, 透過電子顕微鏡の性能向上と普及 が進んだ 1980 年代以前にはナノ構造を有する微細組織を 解析する代表的な手法として，広く用いられてきた ${ }^{1)}$ 。し かしながら, 透過電子顕微鏡やアトムプローブ法等の直接 観察手法が普及した現在，小角散乱法が材料の金属材料の 微細組織解析に使用されることはむしろまれといえるほど 少ない. 本稿では金属材料への利用を前提として小角散乱 法の基礎 - 現状 - 利用例さらに小型線源による中性子小角 散乱測定装置普及への金属材料研究者からの期待を紹介し たい.

\section{2. 小角散乱法の原理と測定・解析法}

小角散乱法は文字通り, 散乱角の小さな領域の散乱強度 を調べ, 析出物やボイド, ナノ粒子等のへテロ構造のサイ ズや量を求める手法である。対象とする角度領域に散乱角 度 $2 \theta$ が 5 以下程度を扱うことが多いが厳密な定義はな い. また, 量子ビームの行路差により生じる量子ビームの 位相のずれを計測するため, そもそも散乱角度で議論すべ きではなく, 行路差と波長との比がパラメータであるた め, 通常は $q=4 \pi \sin \theta / \lambda(\lambda:$ 測定に用いるビームの波 長, $2 \theta$ : 散乱角) というパラメータを使用する. 小角散乱 はこの $q$ 值が $5 \sim 10 \mathrm{~nm}^{-1}$ 以下の散乱を対象とする手法で ある2).

図 1 に小角散乱測定で得られるプロファイルの意味を 模式的に示した. 周知の通り, 結晶構造解析で利用する粉 末回折領域では原子面の周期性の情報が得られる。構造の もつ周期（面間隔など）が大きくなるほどにピークの出現 する領域は低角度側へシフトする. 酸化物や高分子材料等 では材料中に存在する長周期の構造に由来するピークが小 角領域にも出現する。 この場合, 周期性 $d$ は Bragg の式

*原稿受付 平成 25 年 7 月 22 日

**北海道大学工学研究院量子理工学部門（札幌市北区北 13 条西 8 丁目）

*** JFE スチールスチール研究所（千葉市中央区川崎町 1 番地）
を $q$ で書き換えた式 $d=2 \pi / q$ として求められる. 析出物 等でも体積分率が大きくなると粒子間の干渉によりピーク が出現し，ピーク位置から粒子間距離が求められることも ある. とはいえ，析出物等を扱う金属材料研究では小角域 にピークが出現するケースは少数派であり，より利用頻度 の高い解析は, 析出物等のへテロ構造のサイズ情報を得る ことであろう。この方法で比較対象とすべき回折情報は回 折ピークの線幅解析である. 回折実験の場合, 線幅にはひ ずみ情報（結晶構造の周期性の乱れに起因）とサイズ情報 （結晶サイズが有限であることに起因）が含まれる。これ


図 1 小角散乱法と回折法の類似点と相違点：(a) (b) サイズの異 なる粒子からの回折点の模式図, (c) 対応する回折パターン (点線：粒径 $500 \mathrm{~nm}$, 実線：同 $20 \mathrm{~nm}$, 破線：同 $5 \mathrm{~nm}$ ) : 000 ピークと 110 回折ピークはサイズ効果で同じように広がる. いずれも装置起因のビームの広がりをのぞいた理想的な状態 を仮定している．（c）では全体積が一定となった場合の強度 を計算している. (c) 内の小図形は点線部を拡大し, 両対数 表示したもの. 小角散乱ではピーク形状を詳細に解析するた めに, 両対数表示されることが多い. 
に対し，小角散乱プロファイル幅にはサイズ情報のみが含 まれる，どちらのケースも強度の極大となるピーク位置で は散乱波の位相が揃う条件を満たしているが，回折ピーク の場合はピーク位置において結晶を構成する原子位置 $\boldsymbol{r}$ （ $i$ 原子の位置べクトル）の差異により生じる行路差 $2 \boldsymbol{q} \cdot \boldsymbol{r}$ $(\boldsymbol{q}$ : 散乱ベクトル，結晶では面間隔 $d$ を用いて記述する と $2 d \sin \theta)$ が存在し, その行路差がたまたま波長の整数 倍となる Bragg 条件を満たしているために，散乱波の位 相差が生じず，振幅の 2 乗である散乱強度にピークが出現 する。 これに対し, 小角散乱法では $\boldsymbol{q} \cdot \boldsymbol{r}=0$ すなわち行 路差がそもそもない条件からスタートしている。 この違い が結晶の周期性の乱秃，すなわち歪みの情報を前者は含 み，後者は含まないということと対応している，どちらの 場合も, 行路差に起因する散乱波の位相差がない条件 $(q=0$ もしくは $q=2 \pi / d)$ からずれていく過程で散乱体の サイズに依存したピーク強度変化が「どちらの場合も同じ よう」に出現する（図 1 参照）。このうち, 装置パラメー 夕の評価が簡単でかつひずみ情報との区別が容易な小角領 域でサイズ情報を解析するのが小角散乱法である。なお， $q=0$ の散乱強度として観測される波は物質と相互作用せ ずに透過してきた波とは異なることに注意いただきたい （ただし，実際には区別できない)。このため，小角散乱で 到達できる $q$ の最小值には必ず限界がある。この観測でき る $q$ の最小值をより小さくするためには入射する量子ビー ムの発散角を抑え, 検出器位置におけるビーム径を極小化 する必要がある。この目的で，小角散乱装置の多くが量子 ビーム線源から試料までの距離が通常の回折装置とくらべ 長大となっている。 さらに小角領域を拡大して測定するた めに, 試料位置から検出器までの距離も大きくとる必要が ある。これに伴い，X線や中性子の行路中にある空気に よる散乱が無視できなくなるためほとんどの小角散乱装置 では X 線や中性子の飛行経路に真空パス（高真空である 必要はない）を備えている。これらの結果，多くの回折装 置と小角散乱装置とでは外観が大きく異なっている。図 2 に一例として, 東海村原子力機構の研究用原子炬に設置さ れた中性子小角散乱装置 SANS-J の外観写真を示した. 本装置では小角散乱法の代表的な測定法である透過法を採 用している。この方法では測定に使用するX 線や中性子 などの量子ビームを試料面に垂直に入射し，透過側で散乱 強度を測定する。それわえ，測定体積の評価が容易でバッ クグラウンドの差し引きも単純であり，材料中に含まれる 析出物等のへテロ構造の平均サイズや数密度の定量的な評 価を比較的容易に行える。

ヘテロ構造が 1 種類の場合の小角散乱プロファイル $I(q)$ は以下の式で表される。

$$
I(q)=N(\Delta \rho V)^{2} F^{2}(q)
$$

ここで $N$ はへテロ構造の数密度, $V$ はへテロ構造一個あ たりの体積， $\Delta \rho$ は後述する散乱長密度差である． $F(q)$ は 形状因子と呼ばれ，プロファイル幅を決定する項である. この形状因子は理論的に求められており, 球体, 球殼, 楕

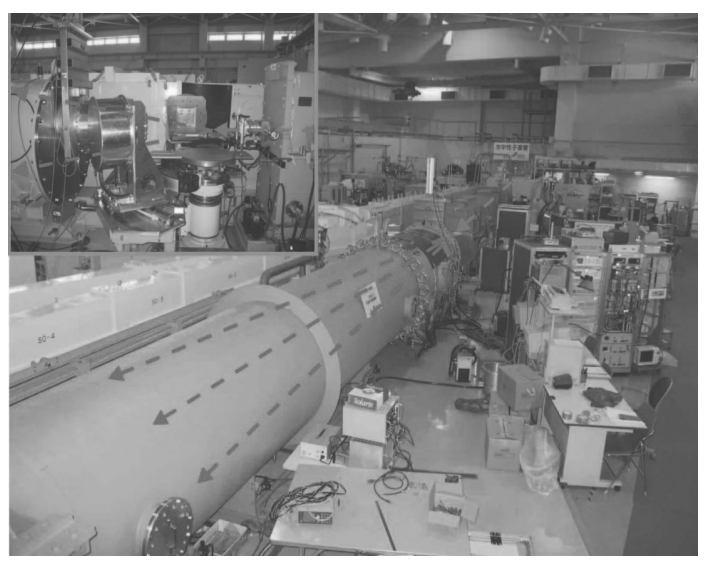

図 2 中性子小角散乱装置 SANS-J の外観図, 円筒が真空パスであ り全長は $20 \mathrm{~m}$ 近くある. 点線のうち, 真ん中の線が入射ビー 厶, それ以外が散乱波を模式的に表している. 左上部は試料 周辺部を拡大したもの.

円体，棒状，円盤状などの代表的な形状の形状因子が与え られている23).

測定するへテロ構造のサイズに分布があれば各サイズの 数密度を $N(R)$ として以下の式に書き換えられる。

$$
I(q)=\Delta \rho^{2} \int_{0}^{\infty} F^{2}(q, R) V^{2}(R) N(R) d R
$$

ここで $V(R)$ および $F(q, R)$ は半径 $R$ のへテロ構造の体 積と形状因子である。多くの解析では測定対象となるへテ 口構造の形状に適した形状因子を選択し，(2)式を用いた プロファイルフィッティングから平均粒子径を求めてい る。また，簡便な方法として Guinier 近似による解析も広 く利用されている4). 繰り返しになるがどちらも測定した プロファイルの広がり〜線幅〜からサイズを決定する方法 であり，Sherrer 法に代表される回折ピークの線幅解析と 基本原理は同じである。（1）式に扔いて $N(\Delta \rho V)^{2}$ ，およ び $(2)$ 式に㧍ける $\Delta \rho^{2} N(R) V^{2}(R)$ はプロファイルの縦軸 方向を決めるパラメータである。 上述の通り，プロファイ ル形状より粒子サイズを決定できるため, 粒子体積は既知 といえる. 残りの $\Delta \rho$ と $N(R)$ がプロファイルの縦軸方向 を決定する，測定に用いた装置のビーム強度，ビーム径， 検出効率を含めて, 装置関数として決定できていれば強度 軸を絶対強度（微分散乱断面積）に置き換えられる。 $\Delta \rho$ はマトリクスの散乱長密度 $\rho_{m}$ とへテロ構造の散乱長密度 $\rho$ の差であり, 散乱長密度は原子数密度 $d_{N}$ と原子分率 $c_{\text {element }}$ を用いて以下の式で表される.

$$
\rho=d_{N} \sum_{\text {element }} b_{\text {element }} c_{\text {element }}
$$

ここで $b_{\text {element }}$ は構成する各元素の X 線または中性子に対 する散乱長である。したがって，測定対象相が既知である 場合， $\Delta \rho$ が分かれば絶対強度化した散乱プロファイルか ら数密度を定量的に決定できる。 


\section{3. 実用材料研究における小角散乱法の役割}

\section{1 新しい小角散乱の利用法}

前述のと抢り, 透過配置の小角散乱法が「へテロ構造の 定量化」という他手法では得難い情報を与える. しかし現 在のところ, 金属材料研究では実際の利用は極めて限定的 である。この主因は「透過率」の問題に起因すると考えら れる，例えば，実用上，特に重要な金属材料である鉄鋼材 料の研究では, 同じく重要なアルミ合金と比較して, 小角 散乱法が用いられる頻度が極端に低い。すなわち， $\mathrm{Cu}-$ $\mathrm{K} \alpha$ を用いた $\mathrm{X}$ 線小角散乱測定では, 厚さ 1 ミクロン程度 まで鉄鋼材料を薄膜化する必要があり，事実上測定は不可 能である。これに対して $\mathrm{Al}$ 合金であれば数 10 ミクロン までの薄膜化で測定が可能である．鉄鋼材料のラボスケー ル測定では Mo-K $\alpha$ 線を用いた小角散乱装置により測定可 能5)であるが，小角散乱装置の性能を示すパラメータの一 つである測定可能な最小 $q$ が（複数の研究分野で共有する 装置としては）不十分となり, 研究目的を特化した装置構 築を行わない限り, 利用は難しい。 それ机え, 金属材料研 究では中性子小角散乱の利用か放射光を用いた小角散乱実 験が中心となっていた。

周知の通り, 中性子の物質・材料研究分野での利用は粉 末回折法で特に進んでいる。この理由として著者らは粉末 回折法の重要性に加えて,「X 線ラボ装置により粉末回折 実験が身近に普及している」ことが大きいと考えている． これに対して，金属材料に扔ける小角散乱測定はX $\mathrm{X}$ 線と いえども大型施設の利用を前提としており，身近で学ぶ機 会もない，そのような状況下で他の回折手法とはやや異な る解析方法を使った手法が普及しないのは当然といわざる を得ない，

この状況が今変わりつつある，X線，中性子ともに第 1 には大型施設性能, 検出器性能の飛躍的向上により, マシ ンタイム自体が増加または増加が期待されることが挙げら れる．第 2 には集光技術，検出効率の増大により，小さな 出力でも十分な散乱強度が得られるようになってきたこと がある.X 線では打㧍むね 10 年前から 2 次元集光ミラー と高効率検出器を備えた小角散乱装置が Mo でも販売され るようになり，ラボスケールで十分な質のデータが得られ るようになってきた ${ }^{677)}$ 。そして，本特集で概説されると おり, 同様な流れ（集光と効率化）がついに中性子にも到 達しつつある。

\section{2 中性子の利便性}

中性子は散乱 - 回折実験に最もよく用いられる 3 つのビ 一ム（電子・X 線・中性子）の中で唯一, 電荷をもたな いため, 原子番号すなわち電子の数とは無関係に原子核の 構造を反映した散乱長 $b$ (散乱振幅) となる。原子サイズ と比較して原子核は著しく小さく, 中性子の散乱確率は電 子・X 線と較べ, 10 から 100 分の 1 程度である。 それゆ え, 試料に対する透過率は強く, 反対に相互作用は弱い. したがって，十分な散乱強度を得るためには大きな試料サ
イズが必要となる。このことは時に中性子散乱実験の弱点 とされるが，大きなサイズの試料が比較的容易に入手でき る実用材料に扔いては「大領域の統計平均情報を一度に取 得できる」ことにつながり, 材料特性と結晶構造や微細組 織との関係を解明する上で大きな利点となる。また，バル ク形状のままで測定できるため, 短時間測定が行えれば材 料製造時の環境を模擬した測定環境中での逐時変化を追跡 する測定が可能である ${ }^{8}$. 本特集で取り上げる小型中性子 源では短時間の逐時測定は困難であるが, 非破壊性と装置 占有性からいったん測定した後に再度, 熱処理や応力を加 えたり，使用環境雲囲気中に暴露した後に，再び，全く同 じ測定条件で「同一試料を長期間にわたり測定する定点観 測」が可能になる。これは, 使用中の材料の構造や組織の 経時変化を知る上で極めて有力な情報をもたらすと期待さ れる。

\section{3 最新の実用材料研究をとりまく環境〜ナノまで作 り込んだ鉄鋼材料〜}

鉄鋼材料は加工熱処理技術により高度な微細組織制御が 可能である．普通鋼は高温ではオーステナイト相（面心立 方格子）であるが, 温度が下がるとフェライト相（体心立 方格子）に変態する．鋼の中の炭素の固溶度はオーステナ イトで大きく、フェライトで小さい. 鋼の冷却速度などの 熱処理と加工の制御で, マルテンサイト, ベイナイト，パ 一ライト，フェライトといった組織，さらにはこれらが複 合した複相組織を設計できる。これにより，外形・寸法だ けなく目的の強度や延性を有する鋼を製造できる。また， マイクロアロイと呼ばれる微量元素を添加し, これらの元 素の炭化物を鋼中に微細に分散させることでも高張力鋼 （ハイテン）を造ることができる，例えば，オーステナイ 卜相中では固溶している $\mathrm{Ti}, \mathrm{Nb}, \mathrm{V}$ などのマイクロアロ イとCはフェライト相への変態中もしくは変態後に数 $\mathrm{nm}$ 程度の極めて微細な炭化物を形成する. 析出制御技術の確 立により, 引っ張り強度が $780 \mathrm{MPa}$ 級の熱延鋼板が開発 され，自動車の足回り部材として活用されている ${ }^{9)}$.この 材料では，炭化物として (Ti, Mo) C の複合炭化物を活用 しており，この析出物が転位移動を妨げる粒子分散強化機 構により鋼を $300 \mathrm{MPa}$ 程度も強化している.このハイテ ンは，母相がフェライトであるため，強度のみでなく， $20 \%$ 程度の優れた伸びと加工性（より具体的には伸びフ ランジ性）を兼備している。（Ti， Mo) C 複合炭化物につ いては, 透過電子顕微鏡や放射光を用いたX 線吸収微細 構造法を用いた精堆な解析が行われている ${ }^{10) 111}$. 粒子分散 強化量の定量的な決定には, 析出物の大きさや析出物間の 平均距離の決定が必須である。電子顕微鏡よりも代表性の 高い平均情報を得る試みとして, 中性子を用いた非破壊的 なサイズ決定が考えられる。この例を次節で紹介する.

\section{4 鉄鋼材料研究への中性子小角散乱の利用}

上述の通り,ナノメートルレベルの組織制御がなされた 鉄鋼材料はすでに安定的に工程生産されており, さらなる 性能向上の上で, ナノスケールといえども統計代表性と精 

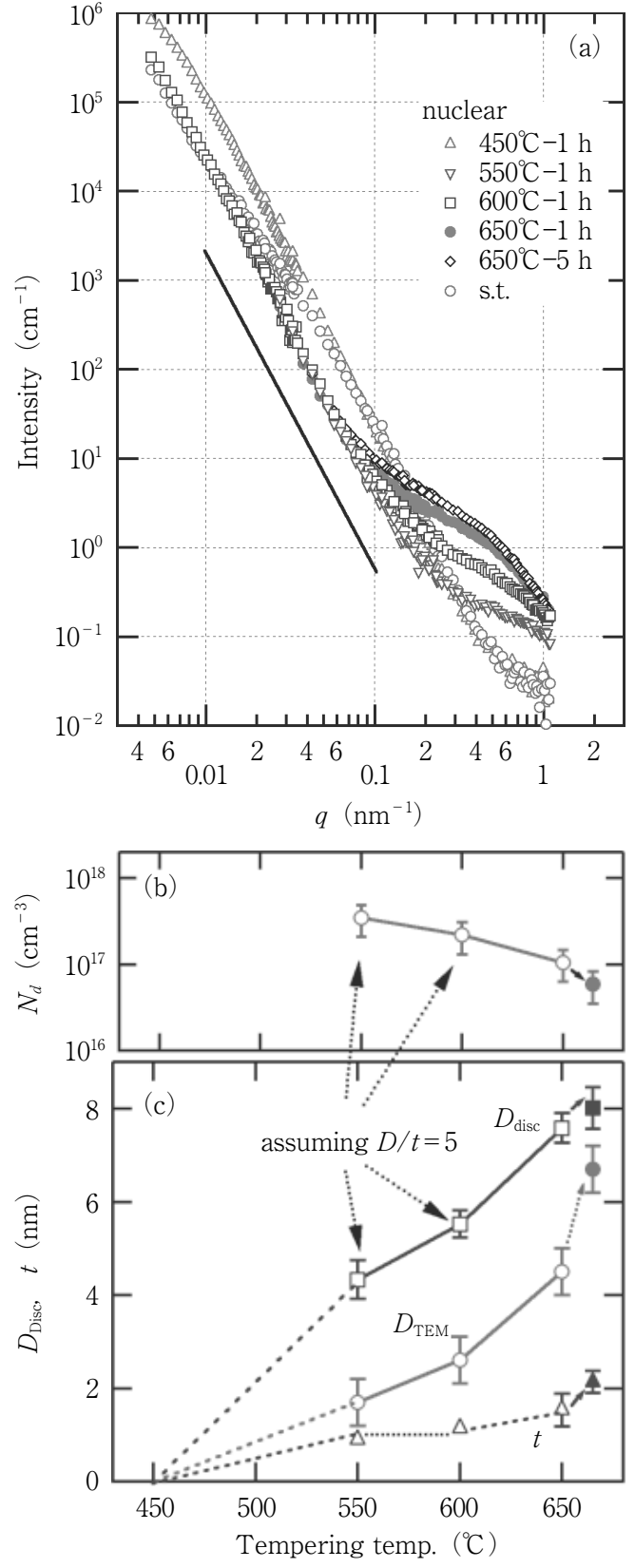

図 3 Ti を単独添加したモデル合金の（a）中性子小角散乱プロファ イル（核散乱成分）と（b） TiC として解析した場合の数密度 変化，および（c）円盤形状として求めた平均サイズ，（c）に はあわせて TEMにより評価したサイズ（ただし，球形を仮定 して処理）を示した ${ }^{12)}$. (鉄鋼協会許諾の上の転載)

度の高い組織情報が必要になっている。このため，われわ れは日本鉄鋼協会の支援のもと，上述した $780 \mathrm{MPa}$ 級の 熱延鋼板のモデル系として，Ti 単独添加系の鋼の系統的

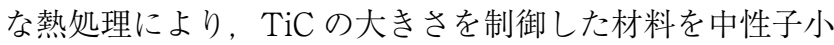
角散乱法で測定・解析を行った ${ }^{12)}$. $15 \mathrm{~mm} \times 15 \mathrm{~mm} \times 2$ $\mathrm{mmt}$ の試料サイズに対し, $10 \mathrm{~mm}$ 直径のビーム径を使用 し, $450 \mathrm{~mm}^{3}$ の体積中の平均的な炭化物の径と厚みを決 定した．図３に測定プロファイルと測定結果を示す。高 温での熱処理ではディスク形状特有の散乱プロファイル形 状となっており，これは電子顕微鏡の測定結果とも一致す る。また，熱処理温度の違いもプロファイル形状の差とし
て明瞭に観測でき，比較的小さなサイズ差でも定量的に変 化を検出できることがわかる.

\section{5 小型中性子源により広がる応用範囲}

ここまで述べてきた通り, 小角散乱法は解析手法に独特 の複雑さがあり, その解釈には専門的な知識と経験が要求 されると思われがちであるが，前節で例示した通り，散乱 プロファイルの差異はだれにでも明瞭に判定できるほどの 差異である。このことは中性子小角散乱測定を手近にかつ 簡便に測定できるような環境が整えば基準材からの逸脱を 容易に判定できることを示唆している。 この特徵は本特集 で概説される小型中性子源が広く普及した際に, 材料研究 へのインパクトが最も強いだろうと著者らが想定する特徵 である。この特徴を活用できれば，材料研究におけるナノ 構造解析の簡便化につながる.

現在の直接観察法では透過電子顕微鏡やアトムプローブ 法では電子が通る厚さへの薄膜化や先端から原子を飛ばす ために必要な針状試料への加工という経験・手間・時間 · コストがかかるプロセスが含まれる，現在はFIB の普及 による試料調整の確実性の向上により，これらの負担は軽 減されつつあるが, 依然として時間とコストにおけるボト ルネックになっている。 また, データの取得すなわち観察 中にも研究者や専従の技術者が長時間装置に付きっきりで 操作を行う必要がある。これに対し, 中性子小角散乱法で は実用材料等の場合には, 試料を適当なサイズ（例えば $20 \mathrm{~mm} \times 20 \mathrm{~mm} \times 2 \mathrm{mmt}$ ）に切断するだけでよい，厚さが 不足する場合は単純に重ねるだけで測定できる。観測対象 がナノ構造であれば特段の表面研磨も不要である。これを 測定装置に挿入し, 適当な測定時間後にデータと試料を回 収するだけでよい. 現在, 北海道大学の小型中性子源専用 小角散乱装置では 6 時間程度, 将来的には 1 時間程度で測 定可能であると考えられる. 得られたデー夕の詳細解析に は経験を積んだ研究者でも 1 日程度は有するが, 標準材と 比較して微細組織がどの程度異なっているかは容易に判定 可能である。したがって，これまでの統計代表性に富む組 織情報の入手手法としての利用に加えて, 材料組織解析の もっとも早い段階において小角散乱を利用し, TEM や AP 解析に進むべき試料の判定, スクリーニングにも利用 できるであろう。

小型中性子源へのもう一つのわれわれの期待はラボスケ 一ルのX 線との複合利用にある。（3)式で記述される散乱 長 $b$ は X 線では原子番号に比例して変化するのに対し, 中性子の散乱長は原子番号に依存しない ${ }^{13}$. このため, 特 定の原子種の組み合わせを選択する〜すなわちある相の濃 度と原子密度を決めると〜散乱長が全く異なった值とな る. 散乱強度はこの散乱長の 2 乗に比例した値となるた め, これを利用することで X 線と中性子の強度比から組 成情報を得ることができる ${ }^{1415)}$. 注目すべきはこの組成比 の情報精度はへテロ構造のサイズに依存しない点である. 材料の合金元素など, 少量の元素の存在状態については最 新の透過電子顕微鏡に付随する各種の分析手法やアトムプ 
ローブ法で詳細な情報が得られるようになってきた。しか し，いずれの方法においてもマトリクス中に埋め込まれた ヘテロ構造の情報にはマトリクスを構成する主要元素の影 響がどうしても含まれてしまうう116). これはへテロ構造の 直径が $1 \sim 2 \mathrm{~nm}$ 以下になると特に顕著である。一方で, 数ナノメートルのへテロ構造の本質を理解する上では主構 成元素の分布状態の情報は不可欠となる. X 線小角散乱 と中性子小角散乱法の強度比較では特定の場合（散乱長の 関係でどちらかの手法で散乱コントラストがほぼゼロにな る場合）を除き，マトリクスの主構成元素がへテロ構造中 にどの程度含まれるかをサイズに関わらず精度よく議論で きる.このことは核生成直前直後の組織形成過程の基礎的 研究にとどまらない.いくつかの合金では直接観察ではへ テロ構造形成が不明瞭であるのに対し，小角散乱法では明 瞭な組織変化を観測できる段階ですでに，機械特性の顕著 な差が確認される例が鉄鋼材料でも見つかりつつあり, 組 織制御による特性向上の新たな方向性として期待でき $3^{6) 14)}$.

\section{4. おわりに}

以上，述べてきた通り，金属材料，特に鉄鋼材料ではす でに，ナノメートルレベルの組織制御がなされた製品が何 万ものスケールで安定的に工程生産されている. 各種金属 材料の可能性をさらに追求していく上で, 電子顕微鏡と中 性子や放射光を利用した解析技術の連携による強化と活用 がますます重要になってきている，残念ながらこれまでは 中性子の利用はあくまでも「特別な研究」に限られてき た。しかしながら，その非破壊性・(本稿ではあまり触れ なかったが) 軽元素に対する感度・統計代表性といった特 徵は電子・X 線にはない特徵であり, かつ実用材料研究 に適した特徵といえる。この中性子を日常的に使える環境 が真に実現されるならば，材料研究に対するインパクトは 極めて大きく, 理化学研究所, 北大, 京大, 名古屋大を中 心として進んでいる小型中性子源の開発への期待は極めて 大きい.

\section{参 考 文 献}

1) G. Kostorz : J. Appl. Cryst, 24 (1991) 444.

2) 大沼正人：金属ナノ組織解析法 (宝野, 弘津編), アグネ不技術セ
ンター, (2006) 297-341.

3) J.S. Pedersen: Advances in Colloid and Interface Sicence, 70 (1997) 171.

4) M. Ohnuma, K. Hono, S. Linderoth, J.S. Pedersen, Y. Yoshizawa and H. Onodera : Acta Mater., 48 (2000) 4783.

5) D.H. Ping, M. Ohnuma, Y. Hirakawa, Y. Kadoya and K. Hono: Mater. Sci. \& Eng. A, 397 (2005) 285.

6) M. Ojima, M. Ohnuma, J. Suzuki, S. Ueta, S. Narita, T. Shimizu and Y. Tomota : Scripta Mater., 59, 313 (2008).

7) M. Ohnuma, J. Suzuki S. Ohtsuka, T. Kaito, S.-W. Kim, M. Inoue and H. Kitazawa : Acta Materia., 57 (2009) 5571-5581.

8) M. Koo, P. Xu, Y. Tomota and H. Suzuki : Scripta Mater., 61 (2009) $797-800$.

9) Y. Funakawa, T. Shiozaki, K. Tomita, T. Yamamoto and E. Maeda: ISIJ International, 44 (2004) 1945.

10）佐藤馨，仲道治郎，山田克美：顕微鏡，40（2005）183.

11) M. Nagoshi, T. Kawano, K. Sato, M. Funakawa, T. Shiozaki and K. Kobayashi : Physica Script, T115 (2005) 480.

12）安原久雄, 佐藤馨, 田路勇樹, 大沼正人, 鈴木淳市, 友田陽 鉄と鋼, 96（2010） 545 .

13）田中功, 大沼正人, 乾晴行, 幾原雄一：ぶんせき, 5,292 (2013).

14) Y. Oba, S. Koppoju, M. Ohnuma, T, Murakami, H. Hatano, K. Sasakawa, A. Kitahara and J. Suzuki : ISIJ International, 51, 1852 (2011).

15) Y. Oba, S. Koppoju, M. Ohnuma, Y. Kinjo, S. Morooka, Y. Tomota, J. Suzuki, D. Yamaguchi, S. Koizumi, M. Sato and T. Shiraga : ISIJ International, 52, 457 (2012).

16) G.R. Odette and D.T. Hoelzer: JOM, 62, 84 (2010).


佐藤 馨

1981 年東北大学理学部物理学科博士課程前期修 了. 1989 年英ケンブリッジ大学 Ph.D. 研究分野 は鉄鋼微細組織解析・設計 先端電子顕微鏡. 著書は極低加速電圧走査電子顕微鏡法 : 応用物 理, 73 (2004) 1328 . 